\title{
Effect of Oxygen Flow Rate on Combustion Time and Temperature of Underground Coal Gasification
}

\author{
Apriansyah Zulatama ${ }^{1}$, Aida Syarif ${ }^{2}$, Muhammad Yerizam ${ }^{3}$ \\ ${ }^{1}$ Applied Master of Renewable Energy Engineering, Politeknik Negeri Sriwijaya, Indonesia \\ ${ }^{1}$ Maintenance Mining Equipment Departement, Akademi Komunitas Industri Pertambangan Bukit Asam, Indonesia \\ ${ }^{2}$ Chemical Engineering Departement, Renewable Energy Engineering Study Program, Politeknik Negeri Sriwijaya, \\ Palembang, Indonesia \\ ${ }^{3}$ Chemical Engineering Departement, Industrial Chemical Technology Study Program, Politeknik Negeri Sriwijaya, \\ Palembang, Indonesia
}

\begin{tabular}{|c|c|}
\hline Article Info & ABSTRACT \\
\hline Article history: & $\begin{array}{l}\text { Underground Coal Gasification (UCG) is a process of converting coal in the } \\
\text { ground into synthetic gas that has economic value. In the UCG process which }\end{array}$ \\
\hline $\begin{array}{l}\text { Received July 11, } 2021 \\
\text { Revised August 10, } 2021 \\
\text { Accepted August 20, } 2021\end{array}$ & $\begin{array}{l}\text { will be carried out in the UCG prototype assisted by the presence of oxygen } \\
\text { as a gasification agent, which this gasification agent will help the process of } \\
\text { burning coal in the ground. The flow rate of oxygen in the process of UCG } \\
\text { affecting the coal combustion temperature and effective flame from burning } \\
\text { coal. The highest temperature at a flow rate of } 51 / \mathrm{min} \text { is } 240^{\circ} \mathrm{C} \text { at an oxygen }\end{array}$ \\
\hline Keywords: & $\begin{array}{l}\text { flow rate of } 31 / \mathrm{min} \text { the highest temperature is } 143^{\circ} \mathrm{C} \text { and at an oxygen flow } \\
\text { rate of } 2 \mathrm{l} / \mathrm{min} \text { the highest temperature is } 135^{\circ} \mathrm{C} \text { and time effective flame at a }\end{array}$ \\
\hline Coal & flow rate of $51 / \mathrm{min}$ ie 80 minutes, effective burning time on the speed of the \\
\hline Underground Coal Gasification & flow rate of $31 / \mathrm{min}$ ie for 120 minutes and time effective flame at a flow rate \\
\hline Flow Rate & of $2 \mathrm{l} / \mathrm{min}$ ie for 165 minutes. This study proves that the greater the oxygen \\
\hline Temperature & flow rate is used as the gasification agent at UCG process the lignite coal \\
\hline Effective Flame & $\begin{array}{l}\text { combustion temperatures will be high and effective flame coal combustion } \\
\text { process will be more brief. }\end{array}$ \\
\hline
\end{tabular}

This is an open access article under the CC BY-SA license.

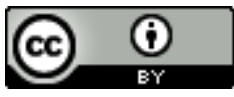

Corresponding Author:

Apriansyah Zulatama,

Maintenance Mining Equipment Departement,

Akademi Komunitas Industri Pertambangan Bukit Asam,

Jl. Bukit Munggu No.1 31712, Muara Enim, South Sumatera, Indonesia

Email: a.zulatama@gmail.com

\section{INTRODUCTION}

Increased energy consumption in Indonesia encourages energy conservation in the field of renewable energy [1]. So that renewable energy becomes one of the options for future energy needs as renewable alternative energy that can support the energy needs of people who still rely on fossil energy sources, one of which is coal. This is supported by the fact that coal is an important energy source for the world, which is used to generate electricity that can generate nearly $40 \%$ of the world's electricity [2]. While Indonesia has coal reserves of as much as 61274 billion tons of which $70 \%$ are brown coal (lignite) [3], but the abundant coal reserves in the future will be reduced [4]. The use of fossil energy such as coal has environmental impacts that must be considered, as does global warming [5], and coal mine wastewater which has a high enough potential to pollute the environment [6], however, coal water waste can be solved by electrocoagulation [7]. The existence of fossil energy is limited and has the potential to pollute the 
environment, needs to be verified as an energy source with the aim of ensuring the availability of clean energy, and the right direction is renewable energy [8].

Many states are developing new and renewable energy, one that would change the quality of coal has a higher sales value, by doing downstream coal with coal gasification methods. In Indonesia, the downstream of coal has been confirmed in law number 3 of 2020, namely the mineral and coal law, especially in article 102 paragraph 1 requiring an increase in mineral and coal added value, which reads "IUP or IUPK holders at the stage of Production Operation activities are required to increase the added value of Minerals in Mining business activities through: a) Processing and Purification for metal mineral mining commodities, b) Processing for non-metal mineral mining commodities, and c) processing for rock mining commodities" [9].

The program is planned to downstream coal gasification method. According to Aida Syarif et al, what is meant by coal gasification is the process of converting coal solids into a synthetic gas mixture that contains fuel [10]. The gasification process still has the potential to make the process of mining, it obviously still requires huge production costs if all calculated starting from the mine explore, the mining process, and downstream processes. Not to mention if the early stages of mining are done, then the potential of environmental destruction will continue to happen, so it still harms the environment and surrounding mines.

One of the downstream processes of coal that are currently being developed in the world is Underground Coal Gasification (UCG). UCG is a new technology that utilizes non-mined coal [11], can provide significant benefits compared to conventional coal mining [12], because UCG is a clean coal gasification technology to safely take advantage of deep coal seams and turn it into a synthetic gas [13]. In addition, UCG is also an alternative gasification technique that is used to exploit chemical energy from coal reserves [14]. Various articles and studies show that UCG is technically feasible and economically attractive as a method to harness energy from coal sources [15]. Economically UCG is a cost-effective and environmentally friendly clean coal technology that converts coal in-situ into combustible gas [16]. Development of underground coal gasification as a need-based business, effectively exploiting coal resources in a clean manner and reducing the tight supply of natural gas in the global industry competition [17]. But in practice, UCG trial preparation in mining operations still need to ensure the safety and stability of the process [18], since the UCG process affects the surrounding rock movement and deformation around the combustion chamber area, the vertical stress distribution of the coal pillar and subsidence [19]. As a clean coal gasification technology, the UCG process with several types of coal will not produce coke around the combustion chamber area [19]. So the underground coal gasification process can be carried out stably [20].

The gasification process that will be carried out in the UCG prototype is assisted by an injection hole, which will help the combustion process in the soilThe injection condition is one of the key parameters to control the product gas quality in the UCG process [21]. The UCG process involves the reaction of oxygen, air or steam with coal carbon and pyrolysis products [14], because oxygen affects the temperature and pressure in the coal gasification process [13]. The higher the oxygen flow rate during the lignite coal gasification process, the higher gasification efficiency is indicated by the increase in reaction temperature and the expansion of the gasification area [21]. However, if there is a decrease in the combustion air flow rate, it will tend to make the combustion temperature smaller which will make the temperature smaller so that the efficiency will also decrease.

One of the things that will be considered in this study the temperature. The high temperature generated during the underground gasification process will not only produce high-temperature thermal stresses around the rock from the combustion area but also change the physical and mechanical parameters of the surrounding rock [22]. The high temperature generated during the underground gasification process will not only produce high-temperature thermal stresses around the rock from the combustion area but also change the physical and mechanical parameters of the surrounding rock [22].

\section{RESEARCH METHOD}

In this section, we will discuss the material to be used in the UCG research, namely MT 47 coal obtained from the Bukit Asam Tanjung Enim mine site, and discuss the research method used, namely the process of burning coal in the prototype underground coal gasification.

\subsection{MATERIAL}

The coal used in this study is a type of lignite with 4700 calories taken from the Muara Tiga Besar (MTB) mine site of PT Bukit Asam at the coordinates of $3^{\circ} 43^{\prime} 16,315^{\prime \prime} L S, 103^{\circ} 42^{\prime} 30,463^{\prime \prime}$, with mine brand MT 47 (4600 - $4800 \mathrm{kcal} / \mathrm{kg}$, ar). A study showed that Underground Coal Gasification with lignite coal using oxygen as a gasification agent may be a viable option as it results in an overall energy efficiency of the process estimated at 59\% [23]. 
Grains of coal used in this study are in-situ grain. In-Situ coal gasification using oxygen is an alternative technique for gasification. In the coal samples which have been taken from the front, will be formed in accordance with the dimensions of the gasification combustion chamber, the length of $18 \mathrm{~cm}$ and a diameter of $12.5 \mathrm{~cm}$ by three samples of in-situ with an average weight of $2.2 \mathrm{~kg}$. The purpose of the establishment of the coal sample is to provide an overview of the prototype model of UCG coal conditions at the time were in the layer below the ground.

\subsection{RESEARCH METHOD}

This research will be carried out using a prototype Underground Coal Gasification (UCG) with a length of $21 \mathrm{~cm}$ and a diameter of $13 \mathrm{~cm}$. UCG prototype is expected to produce syngas. The process carried out at the beginning is making a UCG prototype. The gasification agent included is oxygen $\left(\mathrm{O}_{2}\right)$, because it can maintain the gasification process [24]. Oxygen as a gasification agent is injected into the UCG prototype to increase the calorific value and gas production rate [25]. The oxygen will pass through a inch pipe fed into the coal seam or combustion chamber. The flow rate of oxygen as a gasification agent will be varied, namely $2 \mathrm{l} / \mathrm{min}, 3 \mathrm{l} / \mathrm{min}$, and $51 / \mathrm{min}$, the flow rate of the gasification agent will be regulated using an analog regulator, and each distribution pipe will be given a valve. Aims to determine the ratio between the flow rates.

The impact of different percentage of each gasification agent will certainly have different temperature values. The temperature in the combustion chamber is one of the variables in the combustion process [26]. To determine the temperature of UCG during the combustion stage concerning time studied using a thermocouple [27]. The temperature obtained in the UCG process describes the spread of gasification with the maximum temperature that is expected to be measurable in the coal seam during gasification. [28]. Then the need for monitoring the temperature in the combustion chamber system to maintain stability [29]. Such monitoring is useful for maintaining a safe and efficient UCG [30].

During the combustion process, the gas will pass through the output hole on the prototype. The syngas output hole is only installed one hole using a heat-resistant pipe with a diameter of inch. The process of releasing the gas will go through a cooling bath which is useful for lowering high gas temperatures, then headed to the gas filter for filtering so that the gas cleaner and last through the gas towards the shelter. So that the coal gasification process will produce synthetic gas (syngas) with the main components consisting of carbon monoxide $(\mathrm{CO})$, hydrogen $\left(\mathrm{H}_{2}\right)$, and $\left(\mathrm{CH}_{4}\right)$. [31].

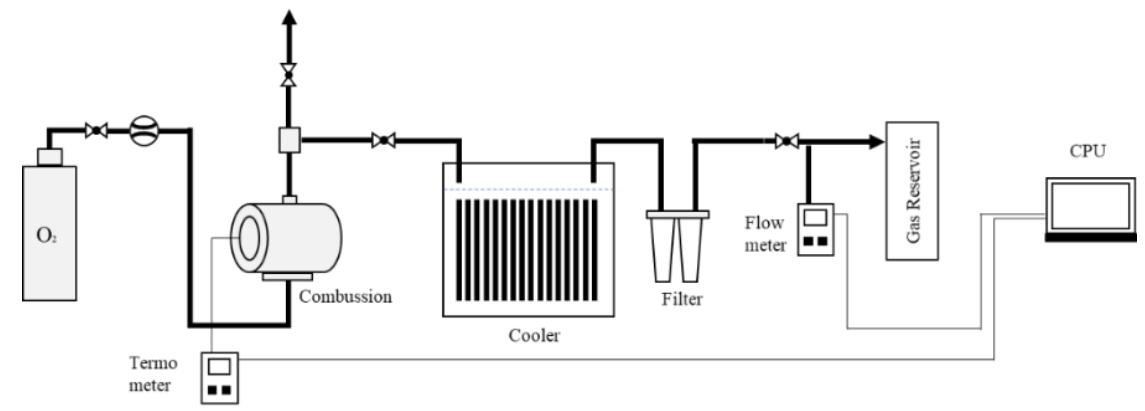

Figure 1. Schematic of Prototype Underground Coal Gasification

\section{RESULTS AND DISCUSSION}

This paper discusses the characteristics of the combustion rate in the Underground Coal Gasification process, with discussion materials namely the characteristics of the MT 47 coal sample, combustion temperature and effective flame.

\subsection{Coal Sample Characteristics}

Each type of coal has a different composition. So it is necessary to test the coal content by proxymite to determine the character and composition of the coal, physically, chemically and fuel properties of the coal that will be used in the gasification process. Proximate analysis of the MT 47 coal type will show the moister content, ash content, volatile meter and fixed carbon in the coal, as shown in table 1. This sampling analysis was carried out at the PT Bukit Asam Penanganan Angkutan Batubara (PAB) work unit laboratory. 
Table 1. Proximate Anailysis

\begin{tabular}{lc}
\hline \multicolumn{2}{c}{ Coal MT 47 } \\
\hline Calori $(\mathrm{kkal} / \mathrm{kg}, \mathrm{ar})$ & 4700 \\
Moisture $(\%, \mathrm{abd})$ & 14,68 \\
Ash Content $(\%$, abd) & 5,3 \\
Volatile Matter $(\%$, abd) & 40,58 \\
Fixed Carbon $(\%$, abd) & 39,45 \\
\hline
\end{tabular}

The proximate testing process of MT 47 liginite coal seen in table 1 is known to have lignite coal calories of $4700 \mathrm{kcal} / \mathrm{kg}$, moisture $14.68 \%$, Ash Content $5.3 \%$, volatile metter $50.58 \%$ and fixed carbon $39.45 \%$.

After conducting proximate testing, an ultimate coal content test is carried out to determine the character and composition of the coal, physically, chemically and fuel properties of the coal that will be used in the gasification process. The ultimate analysis of the MT 47 coal type will show the content of Carbon, Hydrogen, Sulfur, Nitrogen, and Oxygen in the coal as table 2 below. This sampling analysis was carried out at the PT Bukit Asam Penanganan Angkutan Batubara (PAB) work unit laboratory.

\begin{tabular}{lc}
\multicolumn{2}{c}{ Table 2. Ultimate Anailysis } \\
\hline \multicolumn{2}{c}{ Analysis Ultimate Batubara MT 47} \\
\hline Calori (kkal/kg, ar) & 4700 \\
Carbon (\%adb) & 60,66 \\
Hydrogen (\%adb) & 4,39 \\
Nitrogen (\%adb) & 0,69 \\
Sulfur (\%adb) & 1,03 \\
Oxygen (\%adb) & 13,26 \\
\hline
\end{tabular}

The ultimate testing process for MT 47 lignite coal seen in table 2 is known to have Carbon 60.66\%, Hydrogen $4.39 \%$, Nitrogen $0.69 \%$, Sulfur $1.03 \%$, and Oxygen $13.26 \%$.

\subsection{Temperature}

The underground coal gasification process will be seen as the difference in combustion temperature with different combustion oxygen rates, namely $21 / \mathrm{min}, 3 \mathrm{1} / \mathrm{min}$, and $5 \mathrm{1} / \mathrm{min}$. The difference in oxygen flow produces different temperatures, so the temperature will be studied and monitored through a thermometer that appears on the computer every 5 minutes of burning. The thermometer is connected to the thermocouple in the combustion chamber. The temperature results obtained from this study are depicted in a graph which can be seen in Figure 2 below.

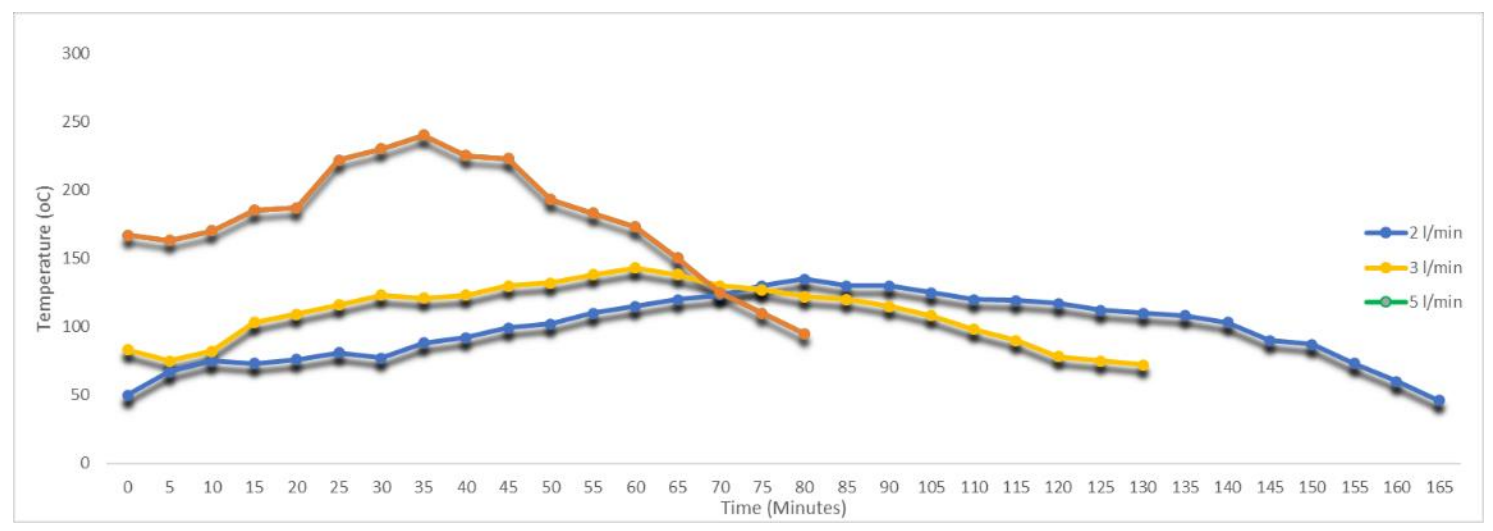

Figure 2. Underground Coal Gasification Combustion Temperature Graph

The temperature graph shown in figure 2 explains that high temperatures generated by using an oxygen flow rate of $21 / \mathrm{min}$ are $135^{\circ} \mathrm{C}$ in the 80 th minute, and the lowest temperature is $46^{\circ} \mathrm{C}$ at 165 minutes, From the 120th minute to the 165th minute, the temperature decreased due to the burning of MT 47 lignite coal in the UCG prototype has been exhausted. Then, when the oxygen flow rate of $3 \mathrm{l} / \mathrm{min}$ generate high temperature namely $143^{\circ} \mathrm{C}$ in the 60th minute, while the lowest temperature generated by $72^{\circ} \mathrm{C}$ the 120 th minute. In the 95th minute to the 120th minute, the temperature decreased due to the burning of MT 47 lignite coal in the UCG prototype has been exhausted. Then the high temperature at the time of the oxygen 
flow rate of $5 \mathrm{~L} / \mathrm{min}$ is $240^{\circ} \mathrm{C}$ in the 35 th minute, while the lowest temperature was $95^{\circ} \mathrm{C}$ at the 80 th minute. From the 60th minute to the 95th minute, the temperature decreased, due to the burning of lignite coal in the prototype MT 47 UCG has been exhausted.

It can be seen that among other flow rates, the oxygen flow rate of $51 /$ min produces the highest temperature, which is $240^{\circ} \mathrm{C}$. So it can be ascertained that the higher the combustion flow rate as a gasification agent in UCG, the higher the combustion temperature.

\subsection{Effective Flame}

In the underground coal gasification process, the combustion time will be monitored through a stopwatch every minute with different combustion oxygen rates, namely $2 \mathrm{l} / \mathrm{min}, 3 \mathrm{l} / \mathrm{min}$, and $5 \mathrm{l} / \mathrm{min}$. The difference in oxygen flow has a different combustion time. The results of the combustion time obtained from this study are depicted in a graph which can be seen in Figure 3 below.

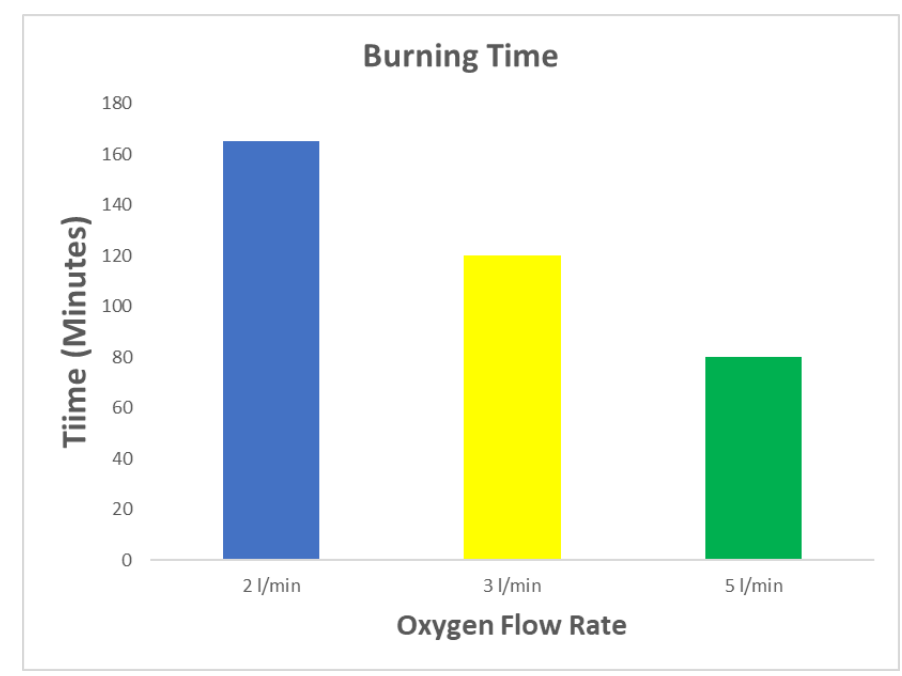

Figure 3. Underground Coal Gasification Burning Time

The burning time graph shown in figure 3 it can be seen that the flow rate of $21 / \mathrm{min}$ has an effective flame time of 165 minutes, a flow rate of $3 \mathrm{l} / \mathrm{min}$ has an effective flame time of 120 minutes and a flow rate of $5 \mathrm{l} / \mathrm{min}$ has an effective flame time of 80 minutes.

Based on the research data above, the high temperature at an oxygen flow rate of $2 \mathrm{l} / \mathrm{min}$ is $135^{\circ} \mathrm{C}$ at the 80th minute, at an oxygen flow rate of $3 \mathrm{l} / \mathrm{min}$ the resulting high temperature is $143^{\circ} \mathrm{C}$ at the 60 th minute and a high temperature at a flow rate of $51 / \mathrm{min}$ is $240^{\circ} \mathrm{C}$. So it can be stated that the largest air flow rate $(5$ $1 / \mathrm{min}$ ) produces the highest temperature and has a shorter effective ignition time while using a lower flow rate of $2 \mathrm{1} / \mathrm{min}$ has the highest temperature of only $135^{\circ} \mathrm{C}$ and has a longer effective ignition time.

\section{CONCLUSION}

Research carried out proved that the greater the oxygen flow rate is used as the gasification agent at the UCG process the lignite coal combustion temperatures will be high and the effective flame coal combustion process will be briefer. It can be proven by the following data:

1. The combustion temperature is influenced by variations in the oxygen flow rate, the highest temperature at a flow rate of $51 / \mathrm{min}$ is $240^{\circ} \mathrm{C}$, at an oxygen flow rate of $31 / \mathrm{min}$ the highest temperature is $143^{\circ} \mathrm{C}$, and at axygen flow rate of $2 \mathrm{l} / \mathrm{min}$, the highest temperature is $135^{\circ} \mathrm{C}$.

2. Burning time effectively is also influenced by variations in the flow rate of oxygen, burning time effectively at a flow rate of $5 \mathrm{l} / \mathrm{min}$ i.e. 80 minutes, burning time effective at a flow rate of $3 \mathrm{l} / \mathrm{min}$ ie for 120 minutes, and burning time effectively at a flow rate of $21 / \mathrm{min}$ i.e. for 165 minutes.

\section{ACKNOWLEDGEMENTS}

The authors would like to thank Yaysan Bukit Asam, Head of the Study Program, Head of the Chemical Laboratory and staff of the Politeknik Negeri Sriwijaya, General Manager of UPTE and the Senior Managers and Managers of PT Bukit Asam who have supported this research. 


\section{REFERENCES}

[1] Rusdianasari, Y Bow and R A N Moulita, "Temperature effect on the biodiesel quality from waste cooking oil by induction heating," Publishing. Journal of Physics, 1450 - 012003, 2020.

[2] Aida Syarif, M. Said, A. Halim PKS, Endang Wiwik and DH, "Characerization of Geochemical Waste Rock on Indicate and Mitigation Acid Mine Drainage at Coal Mining Bukit Asam Tanjung Enim". Proceedings of the 5th Sriwijaya International Seminar on Energy and Environmental Science \& Technology Palembang, Indonesia September 10-11, 2014.

[3] Novia, Lia Cundari, SD Sumbogo Murti and Muhammad Faizal, "CFD Simulation of BCL Process: Effect of Temperature on The Yield Distribution of Product," Proceedings of International Symposium on Sustainable Energy and Environmental Protection (ISSEEP), 2009.

[4] Y Bow, S Effendi, ATaqwa, GRinditya, MY Pratama and Rusdianasari," Analysis of Air Fuel Ratio on Combustion Flames of Mixture Waste Cooking Oil and Diesel using Preheating Method ", International Conference on Sustainable Agriculture, Food and Energy, 709 012004, 2021.

[5] A Taqwa, "Higher Education Role in Supporting Indonesian Government Policy in Developing Renewable Energy", Forum in Research, Science, and Technology, IOP Conf. Series: Journal of Physics: Conf. Series 1167 012010, 2019.

[6] Rusdianasari, S Arita, E Ibrahim and Ngudiantoro, "Reduction of Metal Contents in Coal Stockpile Wastewater using Electrocoagulation", Applied Mechanics and Materials Vol. 391, pp 29-33, 2013.

[7] Rusdianasari, Y Bow and A Taqwa, "Treatment of Coal Stockpile Wastewater by Electrocoagulation Using Aluminum Electrodes", Advanced Materials Research Vol. 896, pp 145-148, 2014.

[8] R Ploetz, Rusdiana and Eviliana, "RENEWABLE ENERGY: ADVANTAGES AND DISADVANTAGES”, Proceeding Forum in Research, Science, and Technology (FIRST) 2016.

[9] Undang-undang nomor 3 Tahun 2020 tentang "Perubahan Atas Undang-Undang Nomor 4 Tahun 2009 Tentang Pertambangan Mineral dan Batubara", 2020

[10] A Syarif, A Aswan, I Rusnadi and Azhar Athif Fadhulullah and Nur Azizah, "Effect of Air Flow and Filter Variation on Coal Gasification Process with The Downdraft System", Jurnal Kinetika, Vol. 11, No. 01, 36-44, Maret 2020.

[11] Mesut Gur and Engin Deniz Canbaz, “Analysis of syngas production and reaction zones in hydrogen oriented underground coal gasification," Published by Elsevier Ltd, Fuel 269 117331, 0016-2361, 2020.

[12] Natalie Christine Nakate and Thomas Kempka," Radial-symmetric well design to optimize coal yield and maintain required safety pillar width in offshore underground coal gasification," Published by Elsevier Ltd. Energy Procedia 125, 27-33, 2017.

[13] Lee S, et all., Handbook of alternative fuel technologies. 2014: crc Press DOI: https://doi.org/10.1201/b17157

[14] Sivachidambaram Sadasivam, Renato Zagorščak, Hywel Rhys Thomas, Krzysztof Kapusta and Krzysztof Stańczyk, "Experimental Study Of Methane-Oriented Gasification Of Semi-Anthracite And Bituminous Coals Using Oxygen And Steam In The Context Of Underground Coal Gasification (UCG): Effects Of Pressure, Temperature, Gasification Reactant Supply Rates And Coal Rank," Published by Elsevier Ltd, 0016-2361, 2020.

[15] Francis Cheng, "Renewable Engines Can't Replace Fossil Fuels Completely" in Newpaper of The Straits Times, 17.12. 2016.

[16] Liangliang Jiang, Zhangxin Chen and S.M. Farouq Ali,' "Thermal-Hydro-Chemical-Mechanical Alteration of Coal Pores in Underground Coal Gasification," Published by Elsevier Ltd, 0016-2361, 2019.

[17] Zou Caineng, Chen Yanpeng, Kong Lingfeng, Sun Fenjin, Chen Shanshan and Dong Zhen.' "Underground coal gasification and its strategic significance to the development of natural gas industry in China," Petroleum Exploration and Development. Volume 46, Issue 2, April 2019.

[18] Surya Kante De, and V Prabu, "Experimental Studies on Humidified/Water Influx $\mathrm{O}_{2}$ Gasification for Enhanced Hydrogen Production in the Context of Underground Coal Gasification," Published by Elsevier Ltd, hydrogen Energy Publications LLC, 0360-3199, 1-14, 2017.

[19] Huaizhan Li, Guangli Guo and Nanshan Zheng, "Influence of Coal Types on Overlying Strata Movement and Deformation in nderground Coal Gasification Without Shaft dan Prediction Method of Surface Subsidence" Published by Elsevier 0957-5820, 302 - 312, 2018.

[20] Piotr Mocek, Marek Pieszczek, Jerzy Swiadrowski, Krzystof, Marian Wiatowski and Krzystof Stanczyk, "Pilot-scale underground coal gasification (UCG) experiment in an operating Mine "Wieczorek" in Poland," Published by Elsevier Ltd 0360-5442, 2016. 
[21] Hamanaka A, Su, F. Q., Itakura, K. I., Takahashi, K., Kodama, J. I., \& Deguchi, "Effect of injection flow rate on product gas quality in underground coal gasification (UCG) based on laboratory scale experiment". development of Co-Axial UCG system. Energies;10(2):238, 2017.

[22] Xiaopeng Liu, Guangli Guoa and Huaizhan Lia," Study on The Propagation Law of Temperature Field in Surrounding Rock of Underground Coal Gasification (UCG) Combustion Cavity Based on Dynamic Thermal Parameters," Published by Elsevier B.V. 12, 1956-1963, 2211-3797, 2019.

[23] Krysztof Kapusta, Marian Wiatowski and Krzysztof Stanczyk, "An Experimental Ex-Situ Study of The Suitability of a High Moisture Ortho-Lignite for Underground Coal Gasification (UCG) Process," Published by Elsevier 0016-2361, Fuel 179, 150-155, 2016

[24] K. Stanczyk, N. Howanies, A. Smolinski, J. Swiaadrowski, K. Kapusta, et al, "Gasification of Lignite and Hard Coal and Oxygen Enriched Air in a Pilot Scale Ex-Situ Reactor for Underground Gasification". Published by Elsevier, 0016-2361, 1953-1962, 2011.

[25] Marek Laciak, Karol Kostur, Milan Durdan, Jan Kacur and Patrik Flegner," The Analysis of The Underground Coal Gasification in Experimental Equipment," Published by Elsevier, 0360-5442, 2016.

[26] Y Bow, Rusdianasari and S Pujiastuti," Pyrolysis of Polypropylene Plastic Waste into Liquid Fuel", International Conference on Sustainable Agriculture, Food and Energy, 347 012128, 2019.

[27] Jianhua Wang, Ziyin Zub, Zuotang Wangc and Guosheng Xu, "The design of ignition systems and a study of the development of the high temperature zone in well-type underground coal gasification," Published by Elsevier, 0016-2361, 269, 117281, 2020.

[28] Couch RG. "Undergound Coal Gasification," Technical Report, CCC/151. London, UK: IEA Clean Coal Centre; 2009.

[29] M Yerizam, S Andayana and U Oktavia, "Effect of Temperature and Starter Concentration on the Fermentation Process in Making MOCAF," IOP Publishing, Journal of Physics: Conference Series. FIRST, 1500 012050, 2020.

[30] Fa-qiang Su, Ken-ichi Itakura, gota Deguchi and Koutarou Ohga, "Monitoring of Coal Fracturing in Underground Coal Gasification by Acoustic Emission Techniques," Published by Elsevier, 0306-2619, Applied Energy 189142 - 156, 2016.

[31] Eugeniusz Krause, Alicja Krzemien and Adam Smonlisnki, "Analysis and Assessment of a Critical Event During an Underground Coal Gasification Experiment," Published by Elsevier, 0950-4230, 33, $173-182,2015$.

\section{BIOGRAPHIES OF AUTHORS}

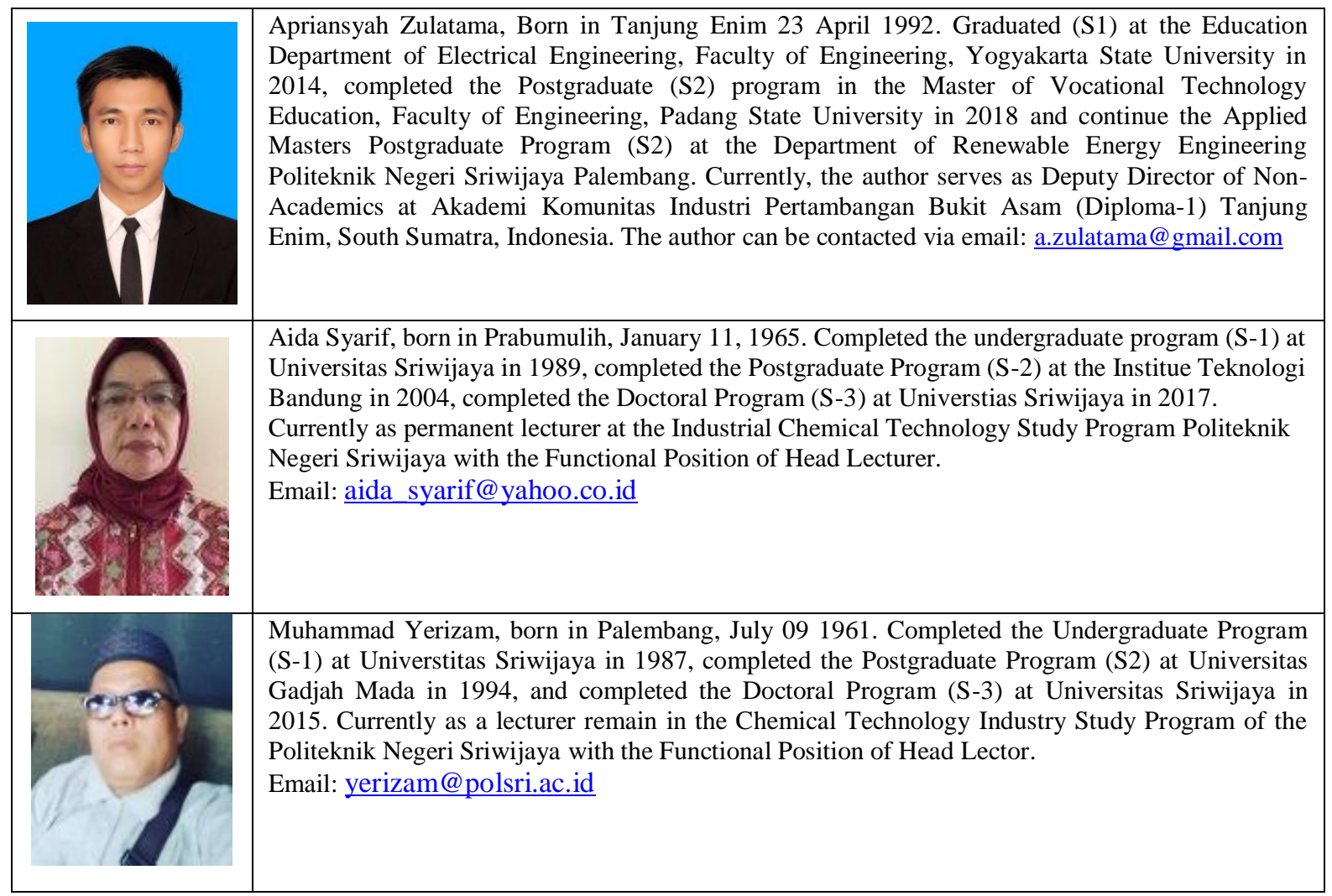

